\title{
PERAN KEPALA DESA DALAM MENINGKATKAN KINERJA APARAT DESA MOPUYA KECAMATAN BULAWA KABUPATEN BONE BOLANGO
}

\author{
Muh Firyal Akbar \\ Program Administrasi Negara Fakultas Ekonomi dan Ilmu Sosial \\ Universitas Muhammadiyah Gorontalo \\ Email :firyalakbar@yahoo.co.id
}

\begin{abstract}
This research aimed to know the role of the head of village in improving the performance of officials Mopuya village in sub district of Bulawa, Bone Bolango regency, to know the factors that impede improvement performance of officials Mopuya village in sub district of Bulawa, Bone Bolango regency. While the benefits of research for academics, are expected to be the brainstorming of knowledge and information that can be used as a reference or grounding in any steps strategy of head village, the practical benefit, that is to increase the knowledge and training to think systematically and bringing insight into the role of head of village in improving the performance of officials village. The research approach used in this research is the phenomenological approach implies that an approach where the researchers trying to understand the meaning of the events of research and its relation to officers who investigated the ordinary people in a particular situation, or the type of research is used descriptive qualitative research.The result of research showed that is the role of the head of village in improving the performance of officials Mopuya village than do the good role with through 4 roles that already been implemented by the head of village. While the factors that impede improvement performance of officials Mopuya village that is the terms of attendance is not on time, lack of knowledge about computers, lack of communication and lack of self-awareness of the officials that not active.
\end{abstract}

Keywords: Role, officials village, Mopuya Vilage

\section{PENDAHULUAN}

Pembangunan nasional bangsa Indonesia adalah pembangunan manusia seutuhnya, yang menuju kepada masyarakat adil, makmur, sejahtra dan untuk mewujudkan diperlukan kesiapan diri sendiri yaitu dengan meningkatkan sumber daya yang ada. Pembangunan nasional yang multi dimensi secara pengelolaannya melibatkan segenap aparat pemerintahan, baik di tingkat pusat maupun di tingkat daerah bahkan sampai di tingkat desa.

Pembangunan desa merupakan wujud suatu masyarakat yang adil dan makmur dalam kehidupan masyarakat desa harus meningkat dan harus kearah yang lebih baik melalui pelaksanaan program-program pembangunan desa serta dalam pembangunan desa dibantu oleh pemerintah desa yang berperan penting dalam pembangunan serta memiliki kewajiban dan tanggung jawab terhadap kemajuan dan kemakmuran masyarakat desa.

Desa adalah kesatuan masyarakat hukum yang memiliki batas-batas wilayah yang berwewenang untuk mengatur dan mengurus kepentingan masyarakat setempat, berdasarkan asal-usul dan adat istiadat setempat yang diakui dan dihormati dalam sistem Pemerintahan Negara Kesatuan Republik Indonesia, sebagai mana yang tercantum dalam Peraturan Pemerintah Nomor 72 Tahun 2005 tentang desa. PP RI. No. 72. Tahun 2005 (Bambang, 2012).

Pemerintah desa adalah organisasi pemerintah desa terdiri atas unsur pimpinan yaitu Kepala Desa, unsur pembantu desa terdiri atas Sekertaris Desa, Kepala Urusan Pemerintah, Kepala Urusan Umum, Kepala Urusan Pembangunan dan Kepala-kepala Dusun. Kepala desa mempunyai tugas menyelengarakan unsur pemerintah pembangunan dan kemasyarakatan. Dalam melaksanakan tugasnya kepala desa mempunyai wewenang memimpin penyelengaraan pemerintah desa berdasarkan kebijakan yang telah ditetapkan bersama BPD (Badan Pemusyawaratan Desa) dan mengajukan rencana peraturan desa (Mangkunegara, 2012).

Kepemimpinan adalah pola penyeluruh dari tindakan seorang pemimpin baik yang 
langsung maupun yang tidak langsung oleh bawahannya. Kepemimpinan menggambarkan kombinasi yang konsisten dari falsafah, keterampilan, sifat dan sikap yang mendasari perilaku seseorang. Kepemimpinan menunjukan secara lansung maupun tidak langsung tentang keyakinan seorang pimpinan terhadap kemampuan kinerja bawahannya.

Kinerja adalah melakukan suatu kegiatan dan menyempurnakan sesuai dengan tanggung jawabnya dengan hasil yang diharapkan. Kinerja dapat diketahui jika individu atau kelompok individu mencapai keberhasilan kerja yang ditetapkan. Kriteria keberhasilan ini berupa tujuan-tujuan tertentu dalam mencapai suatau tujuan, tanpa adanya target dan tujuan kinerja suatu organisasi atau seseorang tidak dapat tercapai atau mungkin dapat diketahui karena tidak ada tolak ukur dalam mencapai suatu keberhasilan.

Berdasarkan uraian di atas dapat dinyatakan kinerja adalah sebagai ekspresi potensi berupa perilaku atau cara seseorang atau kelompok orang dalam melaksanakan suatu kegiatan atau tugas sehingga menghasilkan kinerja dan tanggung jawab pekerjaan yang diberikan kepadanya. Kinerja dapat diukur berdasarkan 3 aspek, yaitu perilaku dalam melaksanakan tugas, kegiatan atau cara untuk menghasilkan suatu hasil kerja dan hasil kinerja. Sehingga kinerjanya kurang baik oleh karena itu kepala desa harus mempunyai motivasi meningkatkan kinerja aparat desa, serta diperlukan inovasi yang baru untuk meningkatkan kinerja aparat dengan cara memberikan ide baru, motivasi dan menfasilitasi serta memberikan pengarahan dalam berkerja terhadap aparat Desa Mopuya yang mempunyai kebiasaan kurang disiplin dan kurang bertanggung jawab terhadap tugas dan kewajibannya, maka peran kepala desa dalam meningkatkan kinerja aparat keseluruhan sangat diperlukan. Peran kepala desa yang diperlukan antara lain sebagai inisiator, motifator, fasilitator, dan mobilisator.

\section{METODE PENELITIAN}

Penelitian ini akan dilakukan di Desa Mopuya Kecamatan Bulawa Kabupaten Bone Bolango. Pemilihan lokasi ini karena tempat lokasi penelitian merupakan tempat yang cukup strategis mudah dijangkau sehingga memudahkan pelaksanaan penelilitian. Dan peneliti telah cukup kenal baik dengan masyarakat yang berada di tempat itu sehingga memudahkan dalam kegiatan penelitian, serta peneliti akan meneliti Kepala Desa, aparat desa dan warga desa.

\section{Desain Penelitian}

Melakukan penelitian ini penulis menggunanakn pendekatan fenomenologis yaitu pendekatan yang mengandung makna bahwa suatu pendekatan yang dimana peneliti berusaha memahami arti peristiwa penelitian dan kaitannya terhadap aparat yang diteliti serta orang-orang biasa dalam situasi tertentu. Sementara jenis yang digunakan adalah penilitian kualitatif deskriptif. Penggunaan jenis dan pendekatan penelitian ini dimaksudkan untuk mendeskripsikan temuan penelitian dalam bentuk kalimat -kalimat berupa keterangan atau pernyataan-pernyataan dari responden sesuai dengan kenyataan yang ada. Sedangkan untuk mendapatkan data penelitian maka peneliti menggunakan teknik partisipatoris dimana peneliti menjadi sebagai instrumen untuk mendapatkan data penelitian.

\section{Teknik Pegumpulan Data}

Teknik pengumpulan data yang digunakan dalam penelitian ini yaitu, 1) Observasi lapangan, teknik ini digunakan untuk menyajikan gambaran realistik perilaku atau kejadian yang nyata dan untuk mengamati kondisi umum lokasi penelitian yang berfokus pada Peran Kepala Desa dalam Meningkatkan Kinerja Aparatur Desa Mopuya. 2) Wawancara, teknik ini merupakan data dimana terjadinya komunikasi secara verbal antara pewawancara dengan informan atau sumber data dan merupakan teknik utama dilakukan untuk mengenal data yang terkait dengan Peran Kepala Desa dalam Meningkatkan Kinerja Aparatur Desa Mopuya Kecamatan Bulawa Kabupaten Bone Bolango. 3) Dokumentasi, teknik ini digunakan sebagai pelengkap data dan untuk mendapatkan data sebagai bahan relevan untuk memperoleh data yang berkait dengan masalah penelitian. Dokumentasi yang digunakan peneliti untuk mendapatkan data-data yaitu data jumlah aparat yang belum maksimal dalam mengerjakan tugasnya dan data-data lain yang diperlukan.

\section{HASIL DAN PEMBAHASAN}

\section{Deskripsi hasil penelitian}

Hasil penelitian menunjukan bahwa Peran Kepala Desa dalam Meningkatkan 
Kinerja Aparat Desa Mopuya Kecamatan Bulawa Kabupaten Bone Bolango dengan menggunakan metode observasi, wawancara dan dokumentasi maka bisa di ketahui bagaimana respon aparat desa terhadap peranperan serta hambatan dan upaya yang dilakukan oleh kepala desa berikut hasil penelitian:

Kepala desa merupakan pemimpin yang harus bertanggung jawab atas semua masyarakatnya, baik tanggung jawab untuk membina masyarakat dan membangun desanya sendiri. Kepala desa memiliki beban berat tidak hanya mengatur masyarakat tetapi juga harus menciptakan lingkungan yang aman damai dan tentram. Dalam mewujudkan hal tersebut kepala desa harus berkerja sama dengan aparat desa, kepala desa tidak dapat menjalankan pemerintahan sendiri tampah bantuan dari aparat desa itu sendiri. Aparat desa dalam memberikan pelayanan terhadap masyarakat tanpa membeda-bedakan golongan masyarakat tertentu dikarenakan memiliki status yang berbeda. Kinerja aparat desa harus efektif agar tercipta keharmonisan terhadap aparat desa dan masyarakatnya.

Peran kepala desa sebagai motivasi/motivator yaitu dengan cara dorongan, rangsangan dan pengaruh atau stimulasi yang diberikan individu ke individu lainnya sedemikian rupa, sehingga orang yang diberikan motivasi tersebut menuruti atau melaksanakan apa yang dimotivasikan secara kritis, rasional dan penuh tanggung jawab. Motivas bisa diberikan seorang individu kepada kelompok, kelompok kepada individu maupun dari kelompok ke kelompok.

Ada pun faktor-faktor penghabat dan kendala dalam peningkatan kinerja aparat desa yaitu:

1. Dari segi kehadiran tidak tepat waktu dalam berkerja, serta tidak memberikan informasi apa bila aparat tidak dapat hadir kekantor desa.

2. Kuranganya pengetahuan komputer dan wawasan aparat desa yang menyebabkan aparat kurang maksimal dalam bekerja.

3. Kurangnya koordinasi yang seimbang antara kepala desa dan aparat desa sehingga kinerja aparat desa tidak sesuai dengan apa yang diharapkan.

4. Kurangnya komunikasi yang kurang dimengerti aparat desa yang menimbulkan kurang produktif dalam menjalakan tugas dan kewajibannya selama ini.
5. Kurangnya kesadaran dari aparat yang kurang aktif dalam menjalankan tugas dan kewajibannya.

Ada pun upaya kepala desa dalam meningkatkan kinerja aparat desa yaitu:

1. Untuk lebih tegas lagi dalam segi kehadiran aparat dengan cara memberikan teguran berupa potongan gaji.

2. Memberikan mereka pelatihan mengetik atau kursus komputer agar bisa mengembangkan kemampuan mengetik serta mengajak studi banding kedesadesa yang lebih maju agar bisa menambah wawasan dan pengetahuan aparat desa.

3. Melakukan koordinasi terus menerus dan teratur agar bisa meningkatkan kinerja aparat yang sesuai dan yang diharapakan kepala desa.

4. Berupaya meningkatkan komunikasi yang baik antara kepala desa dan aparat desa sehingga kinerja aparat desa lebih maksimal dalam menjalakan tugas dan kewajibannya.

Mendatangkan aparat desa yang kurang aktif kekantor desa serta mengklarifikasi apa penyebab menjadikan dia kurang aktif di kantor desa, kemudia mengambil keputusan setelah mengetahui alasannya.

\section{KESIMPULAN}

Sehubungan dengan hasil penelitian dan pembahasan ini yang memiliki 2 indikator, maka dapat ditarik kesimpulan sebagai berikut:

1. Peran kepala desa dalam meningkatkan kinerja aparat Desa Mopuya, yang dilakukan kepala desa yaitu melakukan perannya dengan baik melalui 4 peran yang sudah dilakukan kepala desa pada bab sebelumnya antara lain sebagai motivator, fasilitator, inovator dan mobilisator. Dengan adanya peran-peran yang sudah dilakukan kepala desa sehingga aparat desa lebih meningkatkan kinerjanya dari yang sebelumnya.

2. Faktor-faktor, penghambat peningkatan kinerja aparat Desa Mopuya. Hambatan yang di hadapi kepala desa berupa: (a) dari segi kehadiran tidak tepat waktu dalam berkerja, serta tidak memberikan informasi apa bila aparat tidak dapat hadir kekantor desa. (b) kuranganya 
pengetahuan komputer dan wawasan aparat desa yang menyebabkan aparat kurang maksimal dalam bekerja. (c) kurangnya koordinasi yang seimbang antara kepala desa dan aparat desa sehingga kinerja aparat desa tidak sesuai dengan apa yang diharapkan. (d) kurangnya komunikasi yang kurang dimengerti aparat desa yang menimbulkan kurang produktif dalam menjalakan tugas dan kewajiban selama ini. (e) kurangnya kesadaran dari aparat yang kurang aktif dalam menjalankan tugas dan kewajibannya.

Berdasarkan kesimpulan diatas maka peneliti mengharapkan dalam peran kepala desa dalam meningkatkan kinerja aparat desa sebagai berikut:

1. Kepala desa lebih bisa meningkatkan kinerjanya dengan melaksanakan peran, tugas dan kewajibannya dengan baik.

2. Aparat desa mau mengikuti apa yang dilakukan kepala desa dan lebih bisa aktif lagi dalam bekerja.

Masyarakat lebih bisa mendukung kepala desa dan aparatnya agar ikut berkerjasama demi kepentingan bersama serta demi kemajuan desa.

\section{DAFTAR PUSTAKA}

Bambang W. 2012. Manajemen Kinerja Pemerintah Daerah. Yogyakarta: PT. Laksbang pressindo

Maluyu S P H. 2001. Manajemen Sumber Daya Manusia. Dasar kunci keberhasilan. Jakarta: Haji Masagung

Jakson H J dan Multhis L R. 2006. Faktorfaktor yang Mempengaruhi kinerja (http://www.geocities.com/mas_tri/siste mDP3.pdf). [Diakses 30 Mei 214].

Mangkunegara. 2012. Manajemen Kinerja Pemerintah Daerah. Yogyakarta: PT. Laksbang pressindo

Rivai. 2012. Manajemen Kinerja Pemerintah Daerah. Yogyakarta: PT. Laksbang pressindo 